УAK 657: 658.62

Ю. В. Подмешальська,

к. е. н., Аоцент, доцент кафедри обліку, аналізу, оподаткування та аудиту,

Запорізький національний університет, м. Запоріжжя

ORCID ID: 0000-0001-6353-4542

A. B. Корнієнко,

магістрант кафедри обліку, аналізу, оподаткування та аудиту,

Запорізький національний університет, м. Запоріжжя

ORCID ID: 0000-0002-2908-9825

DOI: $10.32702 / 2306-6792.2021 .24 .58$

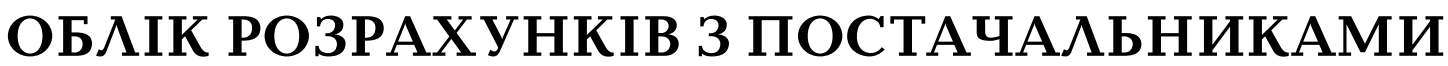 ЗА ВИААМИ ЕКОНОМІЧНОЇ АІЯАЬНОСТІ
}

\author{
Yu. Podmeshalska, \\ $\mathrm{PhD}$ in Economics, Associate Professor, Associate Professor of the Department of Accounting, \\ Analysis, Taxation and Audit, Zaporizhzhia National University, Zaporizhzhya \\ D. Kornienko, \\ Master's student of the Department of Accounting, Analysis, Taxation \\ and Audit, Zaporizhzhia National University, Zaporizhzhya
}

\section{ACCOUNTING FOR PAYMENTS TO SUPPLIERS BY ECONOMIC ACTIVITY}

Бухгалтерський облік розрахунків 3 постачальниками та підрядниками представляє один із елементів інформаційного забезпечення підприємства, в якому існує вхідна та вихідна інформація та яка повинна бути, передусім корисною та достовірною. Визначення потоків інформації та ї̈ документального забезпечення забезпечує ефективність організації бухгалтерського обліку.

Бухгалтерський облік розрахунків з постачальниками та підрядниками складається з бухгалтерських процеАур, оцінки операцій з отримання активів, ї реєстрації, накопиченні інформації, узагальнення інформації та підготовки інформації для її надання підрозділам підприємства та управлінському персоналу. Процес оформлення вхідної інформації в бухгалтерському обліку, ії обробка та відображення в регістрах обліку — це й визначає методологічні аспекти організації бухгалтерського обліку розрахунків з постачальними та підрядниками.

За результатами проведених досліджень визначені основні методологічні аспекти організації бухгалтерського обліку розрахунків з постачальниками та підрядниками.

За результатами аналізу типових помилок у відображенні інформації у фінансовій звітності та Аля їх уникнення запропонована Аналітична відомість бухгалтерського обліку розгорнутого сальдо до рахунку 63 "Розрахунки 3 постачальниками та підрядниками".

Аля контролю дотримання принципів підготовки фінансової звітності та достовірності відображення інформації у фінансовій звітності запропонована Аналітична відомість розрахунків з постачальниками та підрядниками у розрізі контрагентів та взаємовідносин з ними на підставі договорів, угод. Запропонована Аналітична відомість коригування розрахунків з постачальниками та підрядниками після оприбуткування матеріальних запасів, інших активів.

Запропоновані документи аналітичного обліку розрахунків 3 постачальниками та підрядниками допоможуть у практичній діяльності запобігти помилок у відображенні інформації у фінансовій звітності, управлінському персоналу приймати оперативні управлінські рішення.

Accounting for payments to suppliers and contractors is one of the elements of information support of the enterprise, in which there is input and output information and which should be, above all, useful and reliable. Determining the flow of information and its documentation ensures the effectiveness of the organization of accounting.

Accounting for settlements with suppliers and contractors consists of accounting procedures, evaluation of operations to obtain assets, their registration, accumulation of information, generalization of information and preparation of information for its provision to departments and management. The process of registration of input information in accounting, its processing and reflection in the accounting registers - this determines the methodological aspects of the organization of accounting settlements with suppliers and contractors. 
According to the results of the research, the main methodological aspects of the organization of accounting settlements with suppliers and contractors are determined.

Based on the results of the analysis of typical errors in the presentation of information in the financial statements and to avoid them, the Analytical Statement of Accounting for Extended Balance to Account 63 "Settlements with suppliers and contractors" is proposed.

To monitor compliance with the principles of preparation of financial statements and the accuracy of the information in the financial statements proposed Analytical statement of settlements with suppliers and contractors in terms of contractors and relationships with them on the basis of contracts, agreements. The Analytical statement of adjustment of settlements with suppliers and contractors after posting of material stocks, other assets is offered.

The proposed documents of analytical accounting of settlements with suppliers and contractors will help in practice to prevent errors in the presentation of information in the financial statements, management staff to make operational management decisions.

Ключові слова: бухгалтерський облік, аудит, постачальники та підрядники, кредиторська заборгованість, розрахунки, рахунки обліку.

Keywords: accounting, audit, suppliers and contractors, accounts payable, settlements, accounts.

\section{ПОСТАНОВКА ПРОБЛЕМИ}

Постачання сировини та матеріалів для виробництва готової продукції є однією з головних задач для суб'єктів підприємницької діяльності. Питаннями планування потреби і надходження необхідних виробничих запасів займаються центри відповідальності з постачання або відділи постачання. Процес постачання складається 3 певних етапів. Головними 3 яких $€$ такі: планування поставок, укладання договорів на поставку, розрахунки за отримані виробничі запаси, отримання виробничих запасів відповідно до договорів поставок, контроль поставок і розрахунків. Бухгалтерський облік розпочинається з етапу оплати рахунку-фактури, відповідно й виникає об'єкт бухгалтерського обліку - розрахунки з постачальниками та підрядниками.

Завдання бухгалтерського обліку розрахунків з постачальниками та підрядниками забезпечити накопичення, обробку, узагальнення інформації для відображення в бухгалтерському обліку та надання корисної, достовірної інформації про стан розрахунків управлінському персоналу.

Аля виконання завдань бухгалтерського обліку використовуються такі елементи як: первинні документи, рахунки обліку, регістри обліку, інші бухгалтерські документи. Сучасні вимоги до організації бухгалтерського обліку, розвиток інноваційних технологій потребують наукових досліджень для раціоналізації бухгалтерського обліку, оптимізації документального забезпечення, аналізу існуючих форм документального забезпечення, способів їх обробки, забезпечення управлінського персоналу корисною, правдивою, оперативною, звітною інформацією. Саме з тієї точки зору у статті розглядаються проблемні питання бухгалтерського обліку розрахунків з постачальниками та підрядниками.

\section{АНАЛІЗ ОСТАННІХ ДОСЛІДЖЕНЬ ТА ПУБЛІКАЦІЙ}

Бухгалтерський облік кредиторської заборгованості, у тому числі розрахунків з постачальниками та підрядниками мають проблемні питання, тому науковцями проводяться дослідження для їх вирішення. Питання бухгалтерського обліку розглядають такі вчені: С.Ф. Голов, Ф.Ф. Бутинець, О.В. Аишиленко, Г.В. Нашкерська, А.П. Макаренко, В.С. Аень, Н.М. Ткаченко, К.А. Пилипенко, Р.А. Хом'як та інші. У публікаціях обговорюються питання законодавчо-нормативного забезпечення організації бухгалтерського обліку, методологічного забезпечення. Aле проблемні питання мають місце та потребують доопрацювання, дослідження та уточнення.

\section{ВИКЛАД ОСНОВНОГО МАТЕРІАЛУ}

Бухгалтерський облік розрахунків з постачальниками та підрядниками представляє один із елементів інформаційного забезпечення підприємства, в якому існує вхідна та вихідна інформація та яка повинна бути передусім корисною та достовірною. Визначення потоків інформації та її документального забезпечення забезпечує ефективність організації бухгалтерського обліку.

Протягом звітного періоду бухгалтерський облік отримує вхідну інформацію, накопичує іiі, обробляє, узагальнює з відображенням у первинних документах, регістрах обліку, фінансовій звітності. Таку інформацію бухгалтерського обліку яку використовують інші підрозді- 


\begin{tabular}{|c|c|c|c|c|c|}
\hline \multicolumn{6}{|c|}{ Для обліку розрахунків з постачальниками використовуються: } \\
\hline $\begin{array}{c}\text { НП(С)БО } 11 \\
\text { «Зобов’я- } \\
\text { зання» } \\
\text { НП(С)БО } 21 \\
\text { «Вплив змін } \\
\text { валютних } \\
\text { курсів» }\end{array}$ & $\begin{array}{c}\text { МСФЗ, якщо } \\
\text { бухгалтер- } \\
\text { ський облік } \\
\text { ведеться } 3 \\
\text { використан- } \\
\text { ням МСФЗ }\end{array}$ & $\begin{array}{l}\text { Наказ про } \\
\text { облікову } \\
\text { політику }\end{array}$ & $\begin{array}{l}\text { Законодавчо } \\
\text {-нормативні } \\
\text { документи }\end{array}$ & $\begin{array}{l}\text { Інструкція } \\
\text { № } 291 \\
\text { План рахунків }\end{array}$ & $\begin{array}{l}\text { Робочий } \\
\text { План } \\
\text { рахунків }\end{array}$ \\
\hline \multicolumn{6}{|c|}{$\begin{array}{l}\text { Умови визнання зобов'язання } \\
\text { може бути достовірно визначена; } \\
\text { зменшення економічної вигоди в майбутньому внаслідок його }\end{array}$} \\
\hline \multicolumn{6}{|c|}{$\begin{array}{c}\text { Умови визнання доходу звітного періоду } \\
\text { - якщо на дату балансу раніше визнане зобов’язання не підлягає погашенню } \\
\end{array}$} \\
\hline \multicolumn{6}{|c|}{$\begin{array}{l}\text { Особливості заборгованості розрахунків: } \\
\text { - відноситься до операційної діяльності підприємства; } \\
\text { - поточна кредиторська заборгованість }\end{array}$} \\
\hline \multicolumn{6}{|c|}{$\begin{array}{l}\text { Оцінка на дату балансу } \\
\text { - відображаються в балансі за сумою погашення }\end{array}$} \\
\hline \multicolumn{6}{|c|}{$\begin{array}{l}\text { Класифікація розрахунків відповідно до Плану рахунків } \\
\text { - розрахунки з вітчизняними постачальниками; } \\
\text { - розрахунки з іноземними постачальниками; } \\
\text { - розрахунки з учасниками ПФГ }\end{array}$} \\
\hline \multicolumn{6}{|c|}{$\begin{array}{c}\text { Синтетичний облік розрахунків: } \\
\text { Рахунок } 63 \text { «Розрахунки } 3 \text { постачальниками та підрядниками» }\end{array}$} \\
\hline \multicolumn{6}{|c|}{ Рахунок 63 - активно-пасивний рахунок } \\
\hline \multicolumn{3}{|c|}{\begin{tabular}{l|} 
Дебетове сальдо - відображає \\
заборгованість постачальників та \\
підрядників
\end{tabular}} & \multicolumn{3}{|c|}{$\begin{array}{l}\text { Кредитове сальдо - відображає заборгованість } \\
\text { підприємства перед постачальниками та } \\
\text { підрядниками }\end{array}$} \\
\hline \multicolumn{3}{|c|}{$\begin{array}{l}\text { Відображається у складі іншої } \\
\text { дебіторської заборгованості }\end{array}$} & \multicolumn{3}{|c|}{$\begin{array}{l}\text { Відображається у складі поточної } \\
\text { кредиторської заборгованості }\end{array}$} \\
\hline \multicolumn{3}{|c|}{$\begin{array}{l}\text { По дебету кореспондує } 3 \text { кредитом } \\
\text { рахунків: } \\
24,30,31,34,36,37,40,42,46,48,50,51 \\
, 52,55,60,62,64,68,70,71,74\end{array}$} & \multicolumn{3}{|c|}{$\begin{array}{l}\text { По кредиту кореспондує з дебетом рахунків: } \\
15.20,21,22,23,24,28,30,39,42,47,64,68,70,80,84, \\
85,9091,92,93,94\end{array}$} \\
\hline \multicolumn{6}{|c|}{$\begin{array}{l}\text { Аналітичний облік визначається: } \\
\text { - Наказом про облікову політику; } \\
\text { - внутрішніми положеннями про організацію бухгалтерського обліку }\end{array}$} \\
\hline \multicolumn{6}{|c|}{ Регістри обліку: } \\
\hline \multicolumn{6}{|c|}{$\begin{array}{l}\text { Документальне забезпечення: } \\
\text { - типові форми первинних документів; } \\
\text { - самостійно розроблені форми первинних документів відповідно до чинного } \\
\text { законодавства; } \\
\text { - довідки; відомості, інші форми документів для контролю, аналізу, управління }\end{array}$} \\
\hline
\end{tabular}

\section{Рис. 1. Облікова система розрахунків з постачальниками}

ли підприємства, в тому числі управлінський персонал, який повинен приймати обгрунтовані управлінські рішення. Таким чином, бухгалтерський облік повинен надавати корисну, своєчасну, повну, достовірну вихідну інформацію. Визначення видів вихідної інформації та $\dddot{1}$ документальне забезпечення повинно відображатися в Наказі про облікову політику. Вирішення цього питання залежить від професійних здібностей управлінського персоналу, який повинен чітко усвідомлювати необхідну форму, кількість, якість і корисність отриманої інформації.

Бухгалтерський облік розрахунків з постачальниками та підрядниками складається з бухгалтерських процедур, оцінки операцій з отри- мання активів, ї реєстрації, накопиченні інформації, узагальнення інформації та підготовки інформації для ï надання підрозділам підприємства та управлінському персоналу. Процес оформлення вхідної інформації в бухгалтерському обліку, її обробка та відображення в регістрах обліку - це й визначає методологічні аспекти організації бухгалтерського обліку розрахунків з постачальними та підрядниками.

За результатами проведених досліджень нами визначені основні методологічні аспекти організації бухгалтерського обліку розрахунків з постачальниками та підрядниками, представлена характеристика розрахунків та виділені їх особливості (рис. 1). 
Таблиця 1. Аналітична відомість бухгалтерського обліку розгорнутого сальдо до рахунку 63 "Розрахунки з постачальниками та підрядниками"

\begin{tabular}{|c|c|c|c|c|c|c|c|c|}
\hline \multirow{2}{*}{ Зміст операції } & \multicolumn{2}{|c|}{ Показники } & \multicolumn{2}{|c|}{$\begin{array}{c}\text { Відображення } \\
\text { в обліку }\end{array}$} & \multicolumn{2}{|c|}{$\begin{array}{c}\text { Розгорнуте сальдо на } \\
\text { початок періоду }\end{array}$} & \multicolumn{2}{|c|}{$\begin{array}{c}\text { Розгорнуте } \\
\text { сальдо після } \\
\text { здійснення } \\
\text { операції } \\
\end{array}$} \\
\hline & $\begin{array}{c}\text { Вартість активів } \\
\text { відповідно до } \\
\text { рахунку-фактури }\end{array}$ & $\begin{array}{c}\text { Фактична } \\
\text { вартість } \\
\text { отриманих } \\
\text { активів }\end{array}$ & Дебет & Кредит & Дебет & Кредит & Дебет & Кредит \\
\hline 1 & 2 & 3 & 4 & 5 & 6 & 7 & 8 & 9 \\
\hline \multicolumn{9}{|c|}{631 «Розрахунки 3 вітчизняними постачальниками» } \\
\hline \multicolumn{9}{|c|}{ Поставки відповідно до укладених договорів } \\
\hline & & & & & & 100 & & \\
\hline Отримані матеріали & 500 & 300 & 200 & 300 & & & 200 & 400 \\
\hline Отримані матеріали & 800 & 800 & & 800 & & & 200 & 1200 \\
\hline \multicolumn{9}{|c|}{ Поставки відповідно до укладених угод } \\
\hline $\begin{array}{l}\text { Отримані основні } \\
\text { засоби }\end{array}$ & 900 & 900 & & 900 & & & 200 & 2100 \\
\hline Отримані матеріали & 700 & 800 & & 100 & & & 200 & 2200 \\
\hline \multicolumn{9}{|c|}{ Поставки відповідно до замовлень } \\
\hline Отримані матеріали & 600 & 300 & 300 & 300 & & & 500 & 2500 \\
\hline \multicolumn{7}{|c|}{ Сальдо на кінець періоду } & 500 & 2500 \\
\hline
\end{tabular}

Запропонована форма відображення основних методологічних аспектів бухгалтерського обліку розрахунків з постачальниками та підрядниками може бути використана для організації бухгалтерського обліку підприємства 3 урахуванням особливостей підприємницької діяльності. Ао її переваг слід віднести наступні: надає наочність основних аспектів; зручна для проведення аналізу організації бухгалтерського обліку з метою вдосконалення; надає можливість визначення потоків вхідної та вихідної інформації про стан розрахунків 3 постачальниками та підрядниками для отримання оперативної та звітної інформації.

Бухгалтерський облік, у тому числі, і облік розрахунків з постачальниками та підрядниками складається 3 організації синтетичного та аналітичного обліку розрахунків. На підставі інформації синтетичного та аналітичного обліку визначається узагальнена інформація для відображення у фінансовій звітності. Особливого значення набуває правильно організований саме аналітичний облік розрахунків 3 постачальниками та підрядниками. Аослідження типових помилок, які виявляються під час перевірки достовірності інформації бухгалтерського обліку, свідчать про те, що деяких з них можна уникнути, якщо удосконалити саме аналітичний облік.

Інформація бухгалтерського обліку щодо розрахунків з постачальниками та підрядниками впливає на показники Балансу, Звіту про фінансові результати, Звіту про рух грошових коштів. Розкриття інформації про зобов'язання наводиться у Примітках до фінансової звітності. У Балансі наводиться інформація про залишок непогашеної кредиторської заборгованості, яка відображається за кредитом рахунку 63 "Розрахунки з постачальниками та підрядниками". У зв'язку з тим, що рахунок 63 активно-пасивний він може мати і дебетове сальдо. Тому доцільно мати інформацію розгорнутого сальдо розрахунків з постачальниками та підрядниками, про що неодноразово наголошують фахівці з бухгалтерського обліку, науковці. Пропонуємо зразок Аналітичної відомості бухгалтерського обліку розгорнутого сальдо до рахунку 63 "Розрахунки з постачальниками та підрядниками" (табл. 1).

Особливості бухгалтерського обліку розрахунків з постачальниками та підрядниками вимагають ведення більш деталізованого аналітичного бухгалтерського обліку розрахунків для накопичення інформації, контроля бухгалтерського обліку, надання необхідної оперативної, достовірної інформації управлінському персоналу для прийняття оперативних управлінських рішень, а також для її повного та достовірного відображення у фінансовій звітності відповідно до принципів підготовки фінансової звітності та якісних характеристик інформації фінансової звітності.

Переважно підприємства не ведуть деталізований аналітичний бухгалтерський облік, що призводить до порушення принципів складання фінансової звітності, а саме принципу превалювання сутності над формою, відповідно до якого операції обліковуються відповідно до їх сутності, а не лише виходячи з юридичної форми.

Операції по розрахункам з постачальниками та підрядниками призводять до виникнення 
Таблиця 2. Аналітична відомість бухгалтерського обліку розрахунків з постачальниками та підрядниками

\begin{tabular}{|c|c|c|c|c|c|c|c|c|c|c|}
\hline \multirow{3}{*}{$\begin{array}{c}\text { Дата, номер } \\
\text { документу, } \\
\text { визнаного } \\
\text { зобов'язання }\end{array}$} & \multirow{3}{*}{$\begin{array}{l}\text { Термін } \\
\text { оплати }\end{array}$} & \multirow{3}{*}{$\begin{array}{c}\text { Факт. } \\
\text { дата } \\
\text { оплати }\end{array}$} & \multirow{3}{*}{$\begin{array}{c}\text { Сума до } \\
\text { оплати } \\
\text { Кредит } \\
\text { рах.63 }\end{array}$} & \multirow{3}{*}{$\begin{array}{c}\text { Факт. } \\
\text { сума } \\
\text { оплати } \\
\text { Кредит рах. } \\
371\end{array}$} & \multicolumn{2}{|c|}{ Відхилення } & \multicolumn{3}{|c|}{$\begin{array}{c}\text { Вид заборгованості } \text { внаслідок } \\
\text { порушення строків оплати }\end{array}$} & \multirow{3}{*}{ Примітки } \\
\hline & & & & & \multirow{2}{*}{$\begin{array}{c}\text { Дебет } \\
\text { pax. } 63\end{array}$} & \multirow{2}{*}{$\begin{array}{l}\text { Кредит } \\
\text { pax. } 63\end{array}$} & \multirow{2}{*}{$\begin{array}{l}\text { Прост- } \\
\text { рочена }\end{array}$} & \multicolumn{2}{|c|}{\begin{tabular}{|l|} 
Невизначена \\
відносно до:
\end{tabular}} & \\
\hline & & & & & & & & Суми & $\begin{array}{l}\text { Строку } \\
\text { оплати }\end{array}$ & \\
\hline \multicolumn{11}{|c|}{ Відповідно до договорів } \\
\hline № 35 від .... & 10.01 .21 & 10.01 .21 & 90000 & 90000 & - & - & - & - & - & \\
\hline № 36 від ... & 12.01 .21 & - & 100000 & - & - & - & 100000 & - & - & \\
\hline № 37від .... & 15.01 .21 & 20.01 .21 & 200000 & 250000 & 50000 & - & - & - & - & \\
\hline № 38 від .... & 20.01 .21 & - & 300000 & - & - & - & - & 300000 & - & \\
\hline № 39від ... & 22.01 .21 & 25.01 .21 & 500000 & 350000 & - & 150000 & - & - & - & \\
\hline \multicolumn{11}{|c|}{ Відповідно до угоди } \\
\hline & & & & & & & & & & \\
\hline \multirow{2}{*}{\multicolumn{11}{|c|}{ Відповідно до замовлення }} \\
\hline & & & & & & & & & & \\
\hline & & & & & & & & & & \\
\hline \multicolumn{11}{|l|}{ Разом: } \\
\hline \multicolumn{11}{|l|}{ Усього: } \\
\hline \multicolumn{11}{|c|}{ Додаткова інформація } \\
\hline \multirow{2}{*}{\multicolumn{3}{|c|}{ Рахунки обліку }} & \multicolumn{2}{|c|}{ Сальдо на початок місяця } & \multicolumn{3}{|c|}{ Обороти за місяць } & \multicolumn{3}{|c|}{$\begin{array}{c}\text { Сальдо на } \\
\text { кінець місяця }\end{array}$} \\
\hline & & & Дебет & Кредит & Дебе & & Кредит & Дебет & & едит \\
\hline \multicolumn{11}{|c|}{$\begin{array}{l}\text { Рахунок } 63 \text { «Розрахунки } 3 \\
\text { постачальниками та } \\
\text { підрядниками» }\end{array}$} \\
\hline \multicolumn{3}{|c|}{$\begin{array}{l}\text { Рахунок } 371 \text { «Розрахунки за } \\
\text { виданими авансами» }\end{array}$} & & & & & & & & \\
\hline
\end{tabular}

поточного зобов'язання для відображення в бухгалтерському обліку якого необхідно його визнання. Відповідно до п.5 НП(С)БО 11 "Зобов'язання" зобов'язання визнається якщо: оцінка зобов'язання може бути достовірно визначена; існує ймовірність зменшення економічних вигід у майбутньому внаслідок його погашення. Аля узагальнення інформації про стан розрахунків з постачальниками та підрядниками, відповідно до принципів бухгалтерського обліку та фінансової звітності, нами пропонується форма Аналітичної відомості бухгалтерського обліку розрахунків з постачальниками (табл. 2).

У запропонованій Аналітичний відомості:

- виділяються два види кредиторської заборгованості, а саме: прострочена та невизначена відносно суми або строку погашення;

- відображається необхідна інформація для контролю визначення розгорнутого сальдо за рахунками 63 "Розрахунки 3 постачальниками та підрядниками", субрахунком 371 "Розрахунки за виданими авансами", що забезпечує контроль правильності визначення залишків за рахунками для відображення інформації у фінансовій звітності.

Таким чином, інформацію Аналітичної відомості використовують для контролю достовірності відображення інформації про розрахунки з постачальниками та підрядниками у фінансовій звітності:
- Баланс код рядка 1615 - "Поточна кредиторська заборгованість за товари, роботи, послуги";

- Примітки до фінансової звітності відповідно до п.22.2 НП(С)БО 11 "Зобов'язання" необхідно розкрити інформацію про невизначеність зобов'язання відносно суми або строку погашення.

Аостовірність інформації кредиторської заборгованості за розрахунками 3 постачальниками та підрядниками також впливає на достовірність інформації показників Звіту про фінансові результати та Звіту про рух грошових коштів, в яких окремо наводяться показники операційної фінансової та інвестиційної діяльності. Тому підприємства повинні чітко визначати, які операції відносяться до операційної та іншої діяльності. На рахунку 63 "Розрахунки 3 постачальниками та підрядниками" підприємства повинні відображати тільки ті операції, які відносяться до операційної діяльності, а це придбання запасів. Придбання об'єктів основних засобів та нематеріальних активів відносяться до іншої діяльності, повинні відображатися на рахунку 68 "Розрахунки за іншими операціями". Ті ж підприємства, які не використовують рахунок 68, повинні на кінець звітного періоду здійснити певні коригування, для достовірності відображення інформації. 


\begin{tabular}{|c|c|c|c|c|c|}
\hline \multicolumn{6}{|c|}{ Етап визнання зобов’язання відповідно до п.5 НП(С)БО 11 «Зобов’язання» } \\
\hline \multicolumn{6}{|c|}{ Бухгалтерські проиедури } \\
\hline $\begin{array}{c}\text { Отримання } \\
\text { Рахунка - } \\
\text { фактури для } \\
\text { оплати }\end{array}$ & $\begin{array}{c}\text { Перевірка } \\
\text { правильності } \\
\text { оформлення } \\
\text { рахунка- } \\
\text { фактури }\end{array}$ & $\begin{array}{c}\text { Отримання } \\
\text { дозволу на } \\
\text { оплату }\end{array}$ & $\begin{array}{r}\text { Відо } \\
\text { в }\end{array}$ & $\begin{array}{l}\text { раження } \\
\text { бліку }\end{array}$ & $\begin{array}{c}\text { Оформлення } \\
\text { платіжних } \\
\text { документів } \\
\text { перерахування } \\
\text { коштів } \\
\text { постачальнику }\end{array}$ \\
\hline \multicolumn{6}{|c|}{ Етап оприбуткування отриманих активів } \\
\hline \multicolumn{6}{|c|}{ Бухгалтерські прочедури } \\
\hline $\begin{array}{c}\text { Відображення } \\
\text { в обліку }\end{array}$ & $\begin{array}{c}\text { Аналіз } \\
\text { результатів } \\
\text { оприбуткування } \\
\text { матеріалів }\end{array}$ & $\begin{array}{c}\text { Коригування } \\
\text { кредиторської } \\
\text { заборгованості } \\
\text { за отримані } \\
\text { матеріали } \\
\end{array}$ & $\begin{array}{r}\text { Офс } \\
\text { пा } \\
\text { пост }\end{array}$ & $\begin{array}{l}\text { млення } \\
\text { тензї } \\
\text { нальнику }\end{array}$ & $\begin{array}{c}\text { Розрахунок } \\
\text { санкцій за } \\
\text { недотримання } \\
\text { умов поставки }\end{array}$ \\
\hline \multicolumn{6}{|c|}{ Етап поточних бухгалтерських процедур } \\
\hline \multicolumn{2}{|c|}{$\begin{array}{c}\text { Відображення інформації про } \\
\text { отримання матеріалів в } \\
\text { бухгалтерських документах : } \\
\text { - регістрах аналітичного обліку; } \\
\text { - в регістрах синтетичного обліку; } \\
\text { - журналі 3; } \\
\text { - Відомості } 3.3\end{array}$} & \multicolumn{2}{|c|}{$\begin{array}{c}\text { Контроль погашення } \\
\text { кредиторської } \\
\text { заборгованості } \\
\text { постачальником, у разі } \\
\text { недопоставок } \\
\text { матеріалів, заміни } \\
\text { бракованих матеріалів, } \\
\text { інше }\end{array}$} & \multicolumn{2}{|c|}{$\begin{array}{c}\text { Надання необхідної } \\
\text { оперативної інформації } \\
\text { управлінському персоналу } \\
\text { про стан кредиторської } \\
\text { заборгованості за } \\
\text { розрахунками } 3 \\
\text { постачальниками }\end{array}$} \\
\hline \multicolumn{6}{|c|}{ Етап підготовки звітності } \\
\hline \multirow{2}{*}{$\begin{array}{c}\text { Внутрішньої } \\
\text { поточної та на } \\
\text { кінець звітного } \\
\text { періоду }\end{array}$} & \multicolumn{5}{|c|}{ Фінансової звітності } \\
\hline & $\begin{array}{c}\text { Визначення } \\
\text { розгорнутого } \\
\text { сальдо за } \\
\text { рахунком } 63\end{array}$ & $\begin{array}{c}\text { Перевірка } \\
\text { тотожності } \\
\text { інформації } \\
\text { регістрів } \\
\text { аналітичного та } \\
\text { синтетичного } \\
\text { обліку }\end{array}$ & $\begin{array}{r}\text { Пе } \\
\text { досто } \\
\text { праг } \\
\text { відо } \\
\text { інф } \\
\text { об } \\
\text { ре } \\
\text { Голо } \\
\text { об } \\
\text { ві. } \\
\end{array}$ & $\begin{array}{l}\text { евірка } \\
\text { зірності і } \\
\text { гльності } \\
\text { раження } \\
\text { рмації в } \\
\text { ікових } \\
\text { страх, } \\
\text { ній книзі, } \\
\text { ротній } \\
\text { омості }\end{array}$ & $\begin{array}{c}\text { Відображення } \\
\text { інформації про } \\
\text { кредиторську } \\
\text { заборгованість за } \\
\text { розрахунками з } \\
\text { постачальниками } \\
\text { та підрядниками }\end{array}$ \\
\hline
\end{tabular}

Рис. 2. Етапи бухгалтерського обліку розрахунків з постачальниками та підрядниками

Бухгалтерський облік розрахунків 3 постачальниками та підрядниками складається 3 декількох етапів, які будуть відрізнятися від способів оплати, використання попередньої оплати, оплати після отримання матеріальних запасів та інших факторів. Приклад бухгалтерських процедур з використанням попередньої оплати за отримання матеріальних запасів, необоротних активів наведено на рисунку 2.

Аля управління кредиторської заборгованістю за розрахунками 3 постачальниками та підрядниками управлінському персоналу необхідна достовірна інформація про стан розрахунків з постачальниками та підрядниками, причини виникнення заборгованості постачальників перед підприємством та підприємства перед постачальниками. Така заборгованість виникає внаслідок порушення умов договірних поставок, а саме: за кількістю отриманих матеріальних запасів, за забракованими, неякісними матеріальними цінностями, іншими обста- вин. Аля забезпечення управлінського персоналу необхідною інформацією пропонується документ аналітичного бухгалтерського обліку, який призначений відображати саме причини виникнення заборгованості підприємства перед постачальниками та постачальників перед підприємством. Аналіз зафіксованих у документі причин, дозволить управлінському персоналу приймати оперативні управлінські рішення (табл. 3).

Запропоновані нами відомості аналітичного обліку розрахунків з постачальниками та підрядниками не слід розглядати з точку зору збільшення документообігу. Інформація, яка відображається у Відомостях не дублює інформацію бухгалтерського обліку, а має певну мету. Аналіз інформації дозволяє приймати оперативні управлінські рішення, і головне, групування інформації, оцінка зобов'язання відповідає вимогам НП(С)БО, принципам фінансової звітності та якісним характеристикам інформації. 
Таблиця 3. Аналітична відомість коригування розрахунків з постачальниками та підрядниками після оприбуткування матеріальних запасів, інших активів

\begin{tabular}{|c|c|c|c|c|c|c|c|c|c|}
\hline \multirow[b]{2}{*}{$\begin{array}{c}\text { Документ/ } \\
\text { Найменування } \\
\text { запасів, інших } \\
\text { активів }\end{array}$} & \multicolumn{2}{|c|}{ План } & \multicolumn{2}{|c|}{ Фактично } & \multicolumn{3}{|c|}{ Причини відхилень } & \multicolumn{2}{|c|}{$\begin{array}{c}\text { Виникнення } \\
\text { заборгованості }\end{array}$} \\
\hline & К-сть & $\begin{array}{l}\text { Ціна, } \\
\text { (грн) }\end{array}$ & К-сть & Ціна & $\begin{array}{c}\text { Недопо- } \\
\text { ставка/ } \\
\text { збіль- } \\
\text { шення } \\
\text { обсягів } \\
\text { поставки }\end{array}$ & $\begin{array}{c}\text { К-сть } \\
\text { забрако- } \\
\text { ваних }\end{array}$ & Інші & $\begin{array}{c}\text { Підприєм- } \\
\text { ства перед } \\
\text { постачаль- } \\
\text { ником }\end{array}$ & $\begin{array}{c}\text { Постачаль- } \\
\text { ника перед } \\
\text { підприєм- } \\
\text { ством }\end{array}$ \\
\hline 1 & 2 & 3 & 4 & 5 & 6 & 7 & 8 & 9 & 10 \\
\hline \multicolumn{10}{|c|}{ Субрахунок 631 «Розрахунки з вітчизняними постачальниками» } \\
\hline \multicolumn{10}{|c|}{ Поставки відповідно до укладених договорів } \\
\hline & & & & & & & & & \\
\hline & & & & & & & & & \\
\hline & & & & & & & & & \\
\hline \multicolumn{10}{|c|}{ Поставки відповідно до укладених угод } \\
\hline & & & & & & & & & \\
\hline & & & & & & & & & \\
\hline \multicolumn{10}{|c|}{ Поставки відповідно до замовлення } \\
\hline & & & & & & & & & \\
\hline & & & & & & & & & \\
\hline
\end{tabular}

\section{ВИСНОВКИ}

За результатами проведених досліджень визначені основні методологічні аспекти організації бухгалтерського обліку розрахунків 3 постачальниками та підрядниками.

За результатами аналізу типових помилок у відображенні інформації у фінансовій звітності та для їх уникнення запропонована Аналітична відомість бухгалтерського обліку розгорнутого сальдо до рахунку 63 "Розрахунки 3 постачальниками та підрядниками".

Аля контролю дотримання принципів підготовки фінансової звітності та достовірності відображення інформації у фінансовій звітності запропонована Аналітична відомість розрахунків з постачальниками та підрядниками у розрізі контрагентів та взаємовідносин з ними на підставі договорів, угод. Запропонована Аналітична відомість коригування розрахунків з постачальниками та підрядниками після оприбуткування матеріальних запасів, інших активів.

Запропоновані документи аналітичного обліку розрахунків 3 постачальниками та підрядниками допоможуть в практичній діяльності запобігти помилок у відображенні інформації у фінансовій звітності, управлінському персоналу приймати оперативні управлінські рішення.

\section{$\Lambda$ ітература:}

1. Макаренко А.П., Меліхова Т.О., Подмешальська Ю.В., Чакалова Н.С. Бухгалтерський облік: навч.-метод. посібник. Запоріжжя: ЗАIA, $2018.602 \mathrm{c}$.

2. Меліхова Т.О., Чакалова Н.С., Мисливка К.А. Удосконалення обліку доходів від реа- лізації товарів, як інструмент ефективного управління підприємством. Ефективна економіка. 2019. № 2. - URL: http://www.economy.nayka.com.ua/?op $=1 \& z=6888$ (дата звернення: 11.11.2020). DOI: 10.32702/2307-21052019.2.38.

3. Подмешальська Ю.В., Парнюк О.В.Аокументальне забезпечення обліку товарних запасів на підприємстві. Агросвіт. 2020. № 22. C. 97-104. DOI: 10.32702/2306-6792.2020.22.97.

4. Подмешальська Ю.В., Понякіна К.Ю. Облік та аудит виробничих витрат на підприємстві. Інвестиції: практика та досвід. 2020. № 23. C. $64-70$. DOI: $10.32702 / 2306-6814.2020 .23 .64$

References:

1. Makarenko, A.P. Melikhova, T.O. Podmeshalska, Y.V. and Chakalova, N.S. (2018), Bukhhalters'kyy oblik [Accounting], ZDIA, Zaporizhzhya, Ukraine.

2. Melikhova, T. O., Chakalova, N. S. and Myslyvka, K. A. (2019), "Improving the account of income from the implementation of goods, as a tool of effective management of the enterprise", Efektyvna ekonomika, [Online], vol. 2, available at: http://www.economy.nayka.com.ua/?op $=1 \&$ $z=6888$ (Accessed 11 Nov 2020). DOI: 10.32702/ 2307-2105-2019.2.38.

3. Podmeshalska, Yu. and Parniuk, O. (2020), "Documentary accounting of inventories at the enterprise", Agrosvit, vol. 22, pp. 97-104. DOI: 10.32702/2306-6792.2020.22.97.

4. Podmeshalska, Yu. and Poniakina, K. (2020), "Accounting and audit of production costs at the enterprise", Investytsiyi: praktyka ta dosvid, vol. 23, pp. 64-70.DOI: 10.32702/2306-6814.2020.23.64. Стаття надійшла до редакиї 29.11.2021 p. 